\title{
Open Space
}

\section{The research diary as a student/researcher's tool for learning follow-up and implication analysis}

\author{
O diário de pesquisa como instrumento de acompanhamento da aprendizagem \\ e de análise de implicação do estudante/pesquisador (resumo: p. 14) \\ El diario de investigación como instrumento de acompañamiento del \\ aprendizaje y análisis de la implicación del estudiante/investigador (resumen: p. 14)
}

\section{Flávio Adriano Borges ${ }^{(a)}$}

<flavioborges@ufscar.br> (D)

Alexandre Rodrigo Nishiwaki da Silva(b)

<alexandrerns@ufscar.br>

\author{
(a) Departamento de Enfermagem, \\ Centro de Ciências Biológicas \\ e da Saúde, Universidade \\ Federal de São Carlos (Ufscar) \\ Rodovia Washington Luís, Km \\ 235, Jardim Guanabara. São \\ Carlos, SP, Brasil. 13565-905 \\ (b) Departamento de Teorias e \\ Práticas Pedagógicas, Centro \\ de Educação e Ciências \\ Humanas, Ufscar. São Carlos, \\ SP, Brasil.
}

A doctorate process implies a long journey, including some difficulties in perceiving the displacement of learning, thus enabling the doctoral candidate to experience a self-analytical process. Therefore, this article aims to present the use of the research diary during the PhD. program as a powerful instrument to monitor learning and for the analysis of students/researchers' involvement in the development of their research. This is an experience report that uses the theoretical and methodological framework of Institutional Analysis. The diary was written from January 2014 to September 2017, and allowed to map the researchers' trajectory, being also used as an analysis device regarding the involvement with the various institutions that crossed its path. We believe that the use of the diary made it possible to monitor the displacements of the learning process of graduate students and researchers.

Keywords: Graduate teaching. Learning follow-up. Research diary. Institutional analysis. 


\section{Introduction}

Graduate studies have become relevant components of professional training as several professionals, employed or not, search it as a training strategy ${ }^{1}$. One of its functions is to form subjects with the ability to develop teaching and research in their different contexts. For this reason, it is expected that they are committed to the training of other future professionals ${ }^{2}$.

It is possible to identify $\mathrm{PhD}$ program reporting the feeling of insecurity, fear and stress during the $\mathrm{PhD}$ program. The various responsibilities to be assumed, as well as changes in professional roles (from practical specialist to research scientist) and the expectations after the $\mathrm{PhD}$ program pose, by themselves several challenges to be faced by the PhD program in their training ${ }^{3,4}$.

The PhD program may be conceived as composed of an arduous trajectory that goes through a long path, requiring discipline and dedication in the development of a research project and preparation for the life of a researcher and university teacher.

We postulate that Institutional Analysis can contribute in this formative perspective and accompaniment of the knowledge process by $\mathrm{PhD}$ program through the use of its principles in the daily practice and the proposition of the diaries as instruments of record, analysis and research. They make it possible to give shape to the formative trajectory, assist in the self-analysis of the $\mathrm{PhD}$ program and the registration of their movements during the $\mathrm{PhD}$ program.

These tools have the potential to induce reflection regarding their own practice, insofar as the act of writing enables an analytical process of what has been experienced, allowing the recording of what has not been said in order to reflect on the researcher's non-neutrality in the process of research ${ }^{5}$.

There are several types of diaries: the intimate, travel, philosophical, training, moments, institutional, research, among others. All of them, in a certain way, provide the writer the chance "to also become 'subject of the writing process', because when we write, we inscribe our subjectivities" (p. 209-10), and in the reading or re-reading of this instrument, resides the possibility of making them aware.

The research diary, according to the Institutional Analysis, consists of a narrative of the researcher, within the historical-social context, which makes making it possible to restore in a written way the field work, the approximations and distances with the research object and the act of research itself. Diary writing allows a type of reflection proper to the act of writing, denaturalizing the idea of "neutrality" of the act of research, allowing the exposure of everyday experiences, weaknesses and concrete difficulties experienced in the researcher's path ${ }^{7}$.

Through this writing, the students/researchers perform a self-analytical process of their involvements that, for Institutional Analysis, represent the relationships that subjects establish with the institutions, understood as the norms and rules constructed and socially established ${ }^{8}$. This stems from the Lourau's criticism of Freud's concepts of transference and countertransference to collective situations, expanding its scope to the social environment ${ }^{7}$. Involvement, in this view, comprises three dimensions: psycho-affective (libidinal), historical-existential (ideological) and structural-professional (organizational) 9 
The libidinal dimension is related to the subjects' desire. This "tends to question the idea that desire and subjectivity are individual-centered and would result, on a collective level, from the interaction of individual facts" ${ }^{10}$ (p. 232). The libidinal dimension is thus found in the conception of desire at the social level.

The ideological dimension is closely articulated with the libidinal one and indicates the subjects' beliefs. For Marx and Engels ${ }^{11}$, ideology is the system of ideas, representations that dialectically dominate the mind of a man or a social group. The dialectic has its origins in the antiquity "of the pre-Socratics, of the Socratics (Socrates, Plato and Aristotle), of the Stoics (Plotinus, Saint Augustine)"12 (p. 50) and was understood as the principle where, in the same object or social act, its opposite could not be found. This concept of dialectics, following the historical development of society has been evolving until reaching the current point, understanding the idea of unity of opposites as key, or even assuming the concrete possibility of the existence of contradiction.

Therefore, ideology does not consist of something conscious and individual. It is produced from the social existence of the subjects ${ }^{13}$. It is precisely because the researcher is fully engaged in the here and now of his research, that he cannot escape this dimension of implication?.

The organizational dimension concerns the material and temporal base in which the subject is inserted. It is the typical dimension consisting in "the search for elements that have a meaning in reference to the researcher's social work and its socio-economic roots in contemporary society." (p. 117)

Therefore, the research diary, by enabling "a crosscutting writing, with several records allowing to explore the complexity of the subject in question" (p. 211), making it possible to bring to the fore the problematology of involvement: the extratext of the writing diary ${ }^{7}$. In other words, it allows to emerge what is left out and hardly compose scientific productions and course completion works, dissertations and theses. Thus, what was relegated to footnotes, becomes part of the final product as something to be incorporated and analyzed within the context of scientific production ${ }^{6}$.

In this way and due to the difficulty of identifying and analyzing the knowledge learned during the $\mathrm{PhD}$, the displacements achieved in this trajectory, the involvements in the development of a research, as well as taking into account the contributions of the use of the research diary, we have outlined this production. It is an experience report that aims to present the use of the research diary in the $\mathrm{PhD}$. program as a powerful instrument for monitoring the learning and the analysis of the student / researcher's implication in the development of his research.

This production has scientific relevance as it reflects on the use of an instrument for the monitoring and development of research, focusing on the processes that is inherent to the act of research, such as, for example, the ideological, libidinal and organizational relations with the object and field of intervention. 


\section{The diary and the research developed in the context of the PhD. program}

This experience report is based on the research diary written by the first author from January 2014 to September 2017 and describes his subjective reconstructions, showing among other things, the contradiction between the temporality of personal and institutional or bureaucratic production ${ }^{14}$. It consisted of a narrative of the researcher involved with and in the research, in its historical-social context, enabling reflection upon and within his activity keeping the diary ${ }^{5}$, allowing the mapping of the researcher's trajectory, from his insertion to his departure from the $\mathrm{PhD}$. program.

This production is not focused in bringing elements of the empirical research developed by one of the authors in his $\mathrm{PhD}$. program, but rather on the experience in using the research diary as a powerful instrument for conducting scientific studies. Above all, regarding the use of the diary for the self-analytical process of the researcher as part, affecting and being affected by the research developed. However, it is worth mentioning that other instruments were also used in the production of the research data (approved by the Research Ethics Committee under opinion No. 1568447), such as: semi-structured interviews and group meetings with the same study subjects.

The use of the research diary allowed improving the conception and conduction of the studies encompassed by the doctoral research, showing its potential as a methodological procedure in the research. It was used as an instrument for recording, analyzing and ordering experiences as an effort to understand them, enabling the researcher to grasp the context of life itself and to experience the act of researching in its different dimensions. In addition, it could be used to record the analysis procedures, reflections and decisions in conducting the research.

The diary analysis happened at different times of the research, usually before the meetings with the thesis, with the subjects during the interviews or when they were in the groups. They were in situations in which the researcher needed to look at the research process from a transductive perspective ${ }^{15}$. Under this perspective that analyze its relationship with the object of the study (subject-object relationship), it seeks a metastability or assumption in a way to provide a (self) analysis able to be understood and made explicit. This process took place, therefore, individually and based on some principles of Institutional Analysis (above all, the one referring to involvement), marching towards the perspective of understanding the relationships and the productions of the analyzed contexts ${ }^{6}$. Based on this analysis, there was a dialogue with the subjects involved in the research in the group moments as well as restitution of data, envisioning a sharing and deepening of the analysis ${ }^{16}$.

Other principles used in this process were that of an analyzer (the one that "makes the institution speak"); the instituted (forces that tend to keep things as they are); the instituting (pulsating forces, which generate movement) and institutionalization (as a result of the dialectical process of the two previous forces) $)^{7,8,14}$.

It is worth mentioning that the scientific methodology handbooks, when presenting the instruments available for field research, explore their uses and purposes. However, they do not define how researchers live their experiences and difficulties in this process ${ }^{17}$. This causes Bourdieu's ideas ${ }^{8}$ to stand out, emphasizing the need to make explicit: 
[... ] how research work really takes place [making it possible] to have an idea of what goes on in the intimacy of the "laboratory" or, more modestly, of the workshop - in the sense of the Quattrocento artisan or painter: with all hesitations, all embarrassments, all resignations, and so on ${ }^{18}$. (p. 19)

The reflections regarding the data produced were organized in order to enable the group to analyze them collectively, their respective implications and to reflect on the work processes. Additionally, the restitution process collaborated with the analysis of the researcher's implications for the development of his research. These considerations were all written in the research diary to be re-read later, at the moment of final writing of the thesis, allowing to design the follow-up of the $\mathrm{PhD}$. studies, as experienced by the doctoral student at that time.

In other words, diary writing makes it possible to stop and look differently at professional practice and the act of research. It also allows "to look again and write, look, think and write, this way of transferring the material of thoughts and presenting it to the other by means of graphic signs" ${ }^{\prime 19}$ (p. 58), causing permanent analysis and reanalysis of the empirical research development process.

\section{The research diary as an ally in learning follow-up}

Learning follow-up may be understood as an act of caring for those who learn to care for something that is collective, entering into a reciprocal process of fidelity and interrelation ${ }^{20}$.

On the other hand, learning results from social interaction and the sharing of socially constructed meanings, taking place in different historical, social and cultural contexts. Learning happens through the interaction between the organism and its environment, and the acquisition of knowledge occurs through a process that is built throughout the subject's life ${ }^{21}$.

Therefore, it can be said that the research diary makes it possible to accompany the learning process of the student / researcher, being an ally of those who are involved "with" and "in" its object, its research; and this reciprocity and inter -relationship is transferred to the diary through the codes, that is, the writing itself.

It enhances transformative processes by enabling other forms of relationships within the research, awakening the idea of reflections with what was possible to be produced and what has not yet been done, in addition to the effects of this experience ${ }^{22}$.

It is relevant to explain that the use of the research diary will always consist of an instrument to monitor the researcher's trajectory, regardless of the moment in which the research is developed, due to the fact that each research is inscribed in a moment and in the social, political and life context of the researcher and the people who are part of the research.

They said I would have to build a research journal. But how to start this diary? $[\ldots]$ it seems that this is developed by institutional analysts in the construction of their research [...]. (Research Diary, January 2014) 
Revisiting my diary allowed me to identify a certain personal and professional maturation [...] it seems that, at the beginning, I didn't even know how to write properly. (Research Diary, August 2017)

In this sense, and taking the research diary as a powerful tool for analyzing the researcher's involvements, we point to the need to analyze permanently these involvements, because the effects and ideologies can influence the different decisionmaking in the progress of the research, in the daily work, in relationships and in the course of life as a whole ${ }^{23}$.

Based on Freire's ideas ${ }^{24}$ transposed to the educational process developed in graduate school in a dialogical perspective, this concept is central to the analysis of the research diary, since it is done "with" and not "for" the researcher. This practice is based on the idea that researchers and subjects are both equal carriers of culture, i.e. the researchers are not those who give answers, but who help people in problematizing reality ${ }^{24}$ and, when writing about their difficulties, their reach, weaknesses and potentialities in the development of research, enable the perception of what is not yet perceived ${ }^{19}$.

From this perspective, it is impossible to believe that knowledge itself is capable of reproducing or raising awareness. On the contrary, since people (men, women, etc.) are cultural beings, they need to take knowledge into their hands. In Freire's words, it is human nature to "be" and this leads to a series of knowledge of the world in which one is.

I confess that I need to dedicate myself more to my research. It has been so difficult to live this moment [...] The future... well, I don't know what to expect [...] and the only certainty $I$ have is that time is passing and my deadlines are passing too. (Research Diary, July 2016)

Therefore, it is characteristic of human beings to be, as conscience of themselves and the world, in coping relationships with their reality in which, historically, "limit situations" happen. And this confrontation with reality to overcome obstacles can only be done historically ${ }^{25}$ (p. 105).

In other words, the research diary that tries to be truly transformative cannot be based on a concept of completely empty humans "filled" by the world, but, on the contrary, it is necessary to understand the subjects as conscious bodies. The possibility of apprehending the world through research is a dialectical process that ensures that knowledge is not alienated and that it is built based upon the cultural context. 


\section{Analysis of the involvement of the student/researcher through the rese- arch diary: displacements` follow-up}

Involvement is linked to the implicit text in the context of the research diary, which does not necessarily consist of the unconscious or what is hidden. It is linked to the levels or ways of writing that are recommended in the academic and scientific world, being both "authorized" or "prohibited" by the institutions that cross and interfere with the researcher's daily life ${ }^{7}$.

The diary writings made it possible to precisely reveal the mechanisms of functioning of the institutions, evidencing the potential of the involvement analysis for the singularization of the practices, envisioning the overcoming of possible normative captures and reproduction of supposed successful actions ${ }^{19}$.

The research diary made it possible to acknowledge the daily and real experience of this field (not "how to do it, but "how it was done "). This knowledge allowed for a better understanding of the conditions of production of intellectual life, avoiding the construction of a "magical" or "illusory" side of the research (fantasies generated by an "aseptic" reading of the final results of the thesis) ${ }^{14}$.

Thus, it revealed, not so much the static data analysis and interpretation procedures, but a living set of theoretical choices, paths and developments.

From this day on, I will take the project in my own hands [...] maybe it was necessary to go through this painful evaluative process (although I don't agree a bit with the way it was done) to recognize that I need to be the master in my choices [...] would this be a process of analyzing my involvement? (Research Diary, January 2015)

Gatti ${ }^{26}$ affirms that the organization and development of research turns explicit the way we look at our objects, the yearnings we have when "looking at the things of the world".

Building knowledge through research requires great theoretical and conceptual effort to delimit clear and consistent methods. Research, as an epistemological possibility, has specificities and singularities, having as its core the understanding of a given object and, consequently, the objective of transforming current practices.

The research-intervention design process was built from the moment the diary's writer entered the doctorate, in 2014, and the whole retrieval of this path was only possible through careful and analytical reading of the diary.

The writing took place at a time when the writer still did not have the necessary clarity about its use within the theoretical and methodological framework of Institutional Analysis. But when starting to write and rereading what was written from the point of view of the knowledge acquired about what should be a research diary, in the light of this framework, it was a learning experience that took place exactly through practice, i.e., writing. 
Today, I propose to write my doctoral trajectory. I think it will be interesting to return to these pages at the end of the doctorate. Perhaps some connections can be made, or not. Everything is very uncertain and the difficulty of writing seems obvious. (Research Diary, January 2014)

There is a strong tendency to separate knowledge (theory) from doing (practice), giving the theory a higher position in relation to practice, by saying that the former guides the latter. We tend to forget the reverse and also true pathway: that practice originates and validates theory ${ }^{27}$.

In the same direction, Freire ${ }^{25}$ assumes the dialectical relationship between theory and practice as a tool for critical reflection, evading objectivism and subjectivism, understanding these terms, respectively, as empty activism and idealized discourse. Thus, the research intended to be critical, demands from the researcher or from those involved in the research process, a constant exercise of thinking about action based on the theoretical universe and re-signifying the theory through practice.

The process of choosing what is included or not in the research diary generates by itself a reflection process that becomes analytical in the process of questioning the resistance to record certain things and the easiness to record others.

One issue that directly interferes with the scientific writing process is the requirement for funding research projects. This is evident when we observe that many graduate students are enrolled in the doctorate looking for funding for the development of their research and, this fact makes them to guide their writing and project construction towards something that is "able to be financed", i.e., geared towards meeting a market demand.

Getting money and how living in a capitalist system interfere in the way of writing and in our actions and production strategies is something that also crosses the daily life of the doctoral student and, consequently, the development of his research:

Sometimes I think it would be interesting if I just dedicated myself to the development of my doctoral research. Having a scholarship would help me a lot to concentrate exclusively, to this process [...] I cannot understand the reason for so many negatives. I write well, my project is well-founded. (Research Diary, November 2014)

My project remains practically the same [...] Today I have a scholarship and I understand the interests behind the research institution [...] not always what is well written is able to be financed. (Research Diary, November 2016) 
It is worth noting the abrupt reduction in funding for research and graduate scholarships in recent years. Recent news regarding "errors in the system" of the Coordination for the Improvement of Higher Education Personnel (Capes), led to the "disappearance" of more than 6000 graduate scholarships. In addition, about 2000 scholarship cancellations were notified to the National Graduate Association in April 202028.

Money helped to highlight the will, that is, the libidinal dimension of the researcher's involvement with the research. It is not an easy task to dedicate to the theoretical deepening process, which requires time and concentration, while at the same time to develop parallel activities in order to guarantee means for survival. When we talk about the involvement in research, "we refer to all research conditions. Material conditions, where money has an economic and libidinal participation” ${ }^{14}$ (p.16).

The organizational dimension of the involvement with the research was a process that hindered for some time the identification of the thesis among so many different actions, objectives and projects jointly developed. Changing the object of study and transforming it is a factor that is part of the act of research. This process of personal, professional and scientific maturity constituted the doctoral thesis defended, since the object of the final study did not appear a priori, and this path was portrayed, outlined and analyzed through the research diary. Two moments written in the diary clearly show the antagonism and the clear displacement (before and after) of the learning process:

I need to be able to differentiate what is my thesis [...]. Sometimes I think that the development of several projects at the same time hinders my training as a PhD. And my thesis? How will it be? (Research Diary, March 2015)

I did not follow the same path that all $\mathrm{PhD}$. program follow. I had the experience of developing several projects at the same time and I think it was a big difference in my training process as a $\mathrm{PhD}$. (Research Diary, July 2017)

The participation in other research projects allowed the researcher to have more time to analyze the implications of the research as well as broadening his view of the institutional interferences to which he was exposed. This fact was only noticeable through the subsequent reading of the research diary, at the time of writing the thesis. This final process, made possible a "back and forth" movement, highlighting the learning displacements. In the words of Romagnoli ${ }^{29}$ :

[...] the involvement allows to capture the 'trans' aspect of the plans that constitute the object of study, tracking the effects that they cause in the field and the (de) stabilizations that the field produces in the researcher ${ }^{29}$. (p. 50) 
The analysis of the involvement with the university institution was also possible to be evidenced through the relationships established with peers within the University. At the end of the day, institutions speak through the professionals who are part of the organizations ${ }^{14}$.

Relationships seem uneven [...]. There are differences between the components of the group that I cannot quite identify where it comes from. (Research Diary, April 2015)

Power relations go through the group's activities on a daily basis [...] there is clearly a technical and social division of labor. (Research Diary, March 2017)

It is noticeable that the involvement with the university as institution became clearer and more understandable during the doctoral course due to the opportunity to observe the relationships established with colleagues, university environments, professors-students and vice versa, to analyze them and deal with these analyzes within the research diary.

This process was only possible thanks to analytical openings achieved along the way, even in the face of various obstacles. This helped in the course and finalization of the thesis and this proposal responds to the fact that "even in the face of objective impossibilities, we must invest in a real dialogue and in the struggle for transformation. ${ }^{30}$ (p. 92).

This learning aligns itself with Freire's propositions, as it sees the relationship between man/woman-world as the core for the development of human beings in their praxis. This progressive tendency understands education as a cultural practice in which students and teachers seek to apprehend reality through critical awareness geared above all to transformation. Every educational action here is organically related to the analysis of the environment, i.e. the relationship between teachers and students could not be understood by ignoring the institutional context.

All of Freire's formulation of man/woman and the world stems from a basic foundation: the world is not, the world is being. This means assuming the unfinished character of social subjects. It is evident in the work of Paulo Freire, the assumption that the teacher and the student are formed in the educational process: "who forms is also formed and re-formed; while who is formed forms by the process of being formed." ${ }^{31}$ (p. 23).

\section{Final considerations}

Through this article, we reflect on the research diary as a formative and self-analysis element for the student/researcher. For this purpose, we present the methodological instrument in its varied possibilities and the way we use it to follow-up on learning.

It can be used as a tool in the practice of research, through which the researcher records her/his experiences in the investigation, explaining elements commonly discarded 
in traditional research, such as concerns, doubts, feelings, reactions, theoretical reflections raised by the empirical basis under analysis and its implication analyzes. It has a unique constitution that can reveal the paths, choices and movements covered in the research throughout the process, assisting in central issues and becoming the locus for learning, valuing the reflections on the constant immersions and emergence in and off the intervention field.

The research diary has a finitude, ending at the moment the investigation ends. However, it will persist by enabling the elucidation of the subject's learning process, consisting of an instrument that receives and motivates thoughts, interpretations, reflections and analysis. It may be said that it enables a confrontation with human reality, generating interference and disturbances, causing institutions to appear through writing.

It cannot be inferred from this experience report, whether the use of the research diary associated with other theoretical-methodological approaches enables the scope and displacements of learning presented here. This fact certainly points out to one of the limits of this production. However, the existence of scientific studies that address the use of the diary as an instrument for following up and analyzing data is very limited, showing the uniqueness brought by this production in its contribution to the various types of research.

\section{Authors' contributions}

Both authors actively participated in all stages of preparing the manuscript.

\section{Copyright}

This article is distributed under the terms of the Creative Commons Attribution 4.0 International License, BY type (https://creativecommons.org/licenses/by/4.0/deed.en).

\section{(cc) BY}

\section{References}

1. Lopes A, Menezes I. A construção de si como investigador: reflexões sobre os processos de formação pós-graduada. Educ Rev. 2018; 34(71):103-24.

2. Oliveira SSB, Oliveira Filho EC, Bentes AN. A elevação da qualidade da pósgraduação: uma proposta da Universidade Federal do Amazonas. RBPG Rev Bras Pos-Grad. 2014; 11(23):107-26. 
3. Murray C, Stanley M, Wright S. The transition from clinician to academic in nursing and allied health: a qualitative meta-synthesis. Nurse Educ Today. 2014; 34(3):389-95.

4. Ünal A, Interpeler SS; Öncü YA. Percepção de estudantes de doutorado em enfermagem sobre planejamento de carreira e prioridades de pesquisa. Acta Paul Enferm. 2018; 31(5):525-34.

5. Pezzato LM, L’Abbate S. O uso de diários como ferramenta de intervenção da análise institucional: potencializando reflexôes no cotidiano da saúde bucal coletiva. Physis. 2011; 21(4):1297-314.

6. Jesus AF, Pezzato LM, Abrahão AL. O uso do diário como ferramenta estratégica da análise institucional para abordar o cotidiano do profissional de saúde: o caso do dom queixote. In: L’Abbate S, Mourão LC, Pezzato LM. Análise institucional \& saúde coletiva. São Paulo: Hucitec; 2013. p. 206-35.

7. Lourau R. Implicação: um novo paradigma? In: Altoé S. René Lourau: analista institucional em tempo integral. São Paulo: Hucitec; 2004. p. 246-58.

8. Lourau R. A análise institucional. 3a ed. Petrópolis: Vozes; 2014.

9. Barbier R. A pesquisa-ação na instituição educativa. Rio de Janeiro: Jorge Zahar; 1985.

10. Guatarri F, Rolnik S. Micropolítica: cartografias do desejo. 8a ed. Petrópolis: Vozes; 2013.

11. Marx K, Engels F. A ideologia alemã. São Paulo: Boitempo; 2007.

12. Sanfelice JL. Dialética e pesquisa em educação. In: Lombardi JC, Saviani D. Educação e Marxismo. 2a ed. São Paulo: Cortez; 2005.

13. Garcia LBR. A ideologia e o poder disciplinar como formas de dominação. Trans/ Form/Ação. 1988; 11:53-9.

14. Lourau R. René Lourau na UERJ: análise institucional e práticas de pesquisa. Rio de Janeiro: NAPE, UERJ; 1993.

15. Lourau R. Implication transduction. Paris: Anthropos; 1997.

16. Monceau G. A socioclínica institucional para pesquisas em educação e em saúde. In: L’Abbate S, Mourão LC, Pezzato LM. Análise institucional \& saúde coletiva. São Paulo: Hucitec; 2013. p. 91-103.

17. Bellato R, Araújo LFS, Faria APS, Santos EJF, Castro P, Souza SPS, et al. A história de vida focal e suas potencialidades na pesquisa em saúde e em enfermagem. Rev Eletrônica Enferm. 2008; 10(3):849-56.

18. Bourdieu P. O poder simbólico. 15a ed. Rio de Janeiro: Bertrand Brasil; 2011.

19. L’Abbate S, Pezzato LM, Dóbies DV, Botazzo C. O diário institucional nas práticas profissionais em saúde. Mnemosine. 2019; 15(1):40-61.

20. Cornu L. Accompagner: entrer en compagnie. Educ Perm. 2015; (205):1-12.

21. Soeiro E, Oliveira JM, Gomes R, Feliciano AB, Massaro A, Malvezzi E, et al. Caderno do projeto: desenvolvimento da gestão de programas de residência e da preceptoria no SUS - DGPSUS 2018-2020. São Paulo: Hospital Sírio-Libanês, Ministério da Saúde; 2019.

22. Mendes R, Pezzato LM, Sacardo DP. Pesquisa-intervenção em promoção da saúde: desafios metodológicos de pesquisar "com”. Cienc Saude Colet. 2016; 21(6):1737-45.

23. Spagnol CA, L’Abbate S, Monceau G, Jovic L. Dispositif socioanalytique : instrument d'intervention et de collecte de données en recherche qualitative en soins infirmiers. Rech Soins Infirm. 2016; (124):108-17. 
24. Freire P. Educação e atualidade brasileira. 3a ed. São Paulo: Editora Cortez, Instituto Paulo Freire; 2012.

25. Freire P. Pedagogia do oprimido. 62a ed. São Paulo: Paz e Terra; 2016.

26. Gatti B. Algumas considerações sobre procedimentos metodológicos nas pesquisas educacionais. Eccos Rev Cient. 1999; 1(1):63-79.

27. Ayres JRCM. Extensão universitária: aprender fazendo, fazer aprendendo. Rev Med. 2015; $94(2): 75-80$.

28. Brasil. Associação Nacional de Pós-Graduação [Internet]. São Paulo; 2020 [citado 6 Jul 2020]. Disponível em: http://www.anpg.org.br/categoria/noticias/

29. Romagnoli RC. O conceito de implicação e a pesquisa-intervenção institucionalista. Psicol Soc. 2014; 26(1):44-52.

30. Silva JAM, Peduzzi M. Educação no trabalho na atenção primária à saúde: interfaces entre a educação permanente em saúde e o agir comunicativo. Saude Soc. 2011; 20(4):1018-32.

31. Freire P. Pedagogia da autonomia. 60a ed. São Paulo: Paz e Terra; 2019. 
O doutorado consiste em um longo percurso e uma das dificuldades é evidenciar o deslocamento da aprendizagem e possibilitar um processo autoanalítico ao doutorando. Assim, este artigo tem como objetivo apresentar a utilização do diário de pesquisa no percurso de doutoramento como um potente instrumento para o acompanhamento do aprendizado e de análise de implicação do estudante/pesquisador no desenvolvimento de sua pesquisa. Trata-se de um relato de experiência que utiliza o referencial teórico e metodológico da Análise Institucional. O diário foi escrito no período de janeiro de 2014 a setembro de 2017 e possibilitou mapear a trajetória do pesquisador, sendo também utilizado como um instrumento de análise de implicação com as diversas instituições que o atravessaram nesse percurso. Acreditamos que a utilização do diário possibilita o acompanhamento dos deslocamentos do processo de aprendizagem dos (as) estudantes de pós-graduação e pesquisadores.

Palavras-chave: Ensino de pós-graduação. Acompanhamento da aprendizagem. Diário. Análise institucional.

El doctorado consiste en una larga trayectoria y una de las dificultades es poner en evidencia el desplazamiento del aprendizaje y posibilitar un proceso auto-analítico al doctorando. Por lo tanto, esta producción tiene el objetivo de presentar la utilización del diario de investigación en la trayectoria de doctorado como un potente instrumento para el acompañamiento del aprendizaje y del análisis de la implicación del estudiante/investigador en el desarrollo de su investigación. Se trata de un relato de experiencia que utiliza el referencial teórico y metodológico del Análisis Institucional. El diario fue escrito en el período de enero de 2014 a septiembre de 2017 y posibilitó mapear la trayectoria del investigador, utilizándose también como un instrumento de análisis de implicación con las diversas instituciones que lo atravesaron en esa trayectoria. Creemos que la utilización del diario posibilita el acompañamiento de los desplazamientos del proceso de aprendizaje de los estudiantes de postgrado e investigadores.

Palabras clave: Enseñanza de postgrado. Acompañamiento del aprendizaje. Diario. Análisis institucional.

\section{Translator: Félix Héctor Rigoli}

